\title{
Low temperature extremes influence both the presence of palms and palm species richness in the Atlantic Forest, Southern Brazil
}

\author{
Guilherme A. Elias ${ }^{1, \otimes}$; Eduardo L. Hettwer Giehl'; André L. De Gasper ; Joanna \\ M. Tucker Lima ${ }^{4}$ \&obson Dos Santos ${ }^{1}$ \\ ${ }^{1}$ Universidade do Extremo Sul Catarinense. Criciúma, Brazil. ${ }^{2}$ Universidade Federal de Santa Catarina. Florianópolis, Brazil. \\ ${ }^{3}$ Universidade Regional de Blumenau. Blumenau, Brazil. ${ }^{4}$ Montgomery Botanical Center. Coral Gables, USA.
}

\begin{abstract}
Aвstract. This study examines the relationship between climate and species richness and distribution of palms (Arecaceae) in the Brazilian State of Santa Catarina. We use data from the Floristic and Forest Inventory of Santa Catarina and WorldClim - Global Climate Data. We hypothesized that low temperature and precipitation limit palm species richness and distribution in Santa Catarina. For modeling palm species richness, we used a generalized linear model for zero inflated data and to assess reasons behind differences in palm species abundance and species richness across the state, we used a canonical analysis of principal coordinates (CAP). We found that only the distribution of Euterpe edulis Mart. and Syagrus romanzoffiana (Cham.) Glassman showed significant effects of climate, largely because they were the most abundant and frequent species found in sampled plots. Modelling results pinpointed minimum temperature of the coldest month as the strongest predictor of palm species richness and distribution in Santa Catarina. Our results contribute to knowledge about the occurrence of native palms of the Atlantic Forest and their environmental limitations.
\end{abstract}

[Keywords: biodiversity, climate, floristic and forest inventory of Santa Catarina, Palmae, WorldClim]

\begin{abstract}
Resumo. Extremos de baixa temperatura influenciam tanto a presença quanto a riqueza de espécies de palmeiras na Mata Atlântica, sul do Brasil. Este estudo examina a relação entre o clima e a riqueza de espécies e composição de palmeiras (Arecaceae) no estado brasileiro de Santa Catarina. Utilizamos dados do Inventário Florístico Florestal de Santa Catarina e do WorldClim - Global Climate Data. Nossa hipótese é de que a baixa temperatura e a precipitação limitam a riqueza e distribuição de espécies de palmeira em Santa Catarina. Para modelar a riqueza de espécies de palmeiras utilizamos um modelo linear generalizado para dados inflados de zero, e para avaliar as razões por trás das diferenças na abundância e composição de espécies de palmeiras em todo o estado, utilizamos uma análise canônica de coordenadas principais (CAP). Descobrimos que apenas a distribuição de Euterpe edulis Mart. e Syagrus romanzoffiana (Cham.) Glassman apresentaram efeitos significativos do clima, principalmente por serem as espécies mais abundantes e frequentes encontradas nas parcelas amostradas. Os resultados de modelagem apontaram a temperatura mínima do mês mais frio como o mais forte preditor da riqueza e composição de espécies de palmeiras em Santa Catarina. Nossos resultados contribuíram para o conhecimento sobre a ocorrência de palmeiras nativas da Mata Atlântica e suas limitações ambientais.
\end{abstract}

[Palavras chave: biodiversidade, clima, Inventário Florístico Florestal de Santa Catarina, Palmae, WorldClim]

\section{INTRODUCTION}

The Brazilian Atlantic Forest is one of the top biodiversity hotspots in the world (Eisenlohr et al. 2013). It supports 14000 plant species (Forzza et al. 2012), despite continuous exploitation, which has intensified over the last 50 years and reduced the extent of this biome to only $8 \%$ of its original cover (Lucas and Bunger 2015). Palms (Arecaceae) are an important component of forest biodiversity in tropical and subtropical regions across the world (Dransfield et al. 2008). This plant family exhibits remarkable geographic variation in species richness, phylogenetic composition and life forms (Eiserhardt et al. 2011). Especially in the tropics, palms commonly prevail in terms of species richness

Editora asociada: Ana Cingolani guilherme@unesc.net and abundance (Henderson 2002), and vast areas of monodominant palm stands can be found in tropical forest landscapes (Elias et al. 2016).

The distribution of individual plant species and patterns of palm species richness and diversity across different vegetation types are strongly associated with current climate, especially temperature and precipitation, increasing with increasing temperature and water availability (Tomlinson 2006; Eiserhardt et al. 2011; Svenning et al. 2008; Sevegnani et al. 2016). Besides that, large scale spatial patterns in palm species richness and distribution are closely linked to extreme temperatures (Svenning et al. 2008). This is confirmed by the highest numbers of palms found in warm

Recibido:9 de Abril de 2018

Aceptado: 25 de Octubre de 2018 
and humid climates, identifying the palm family as a wet-tropical group (Corner 1966; Balslev et al. 2011). Palm species richness and distribution are further driven by abiotic factors (e.g., soil properties, hydrology and topography), biotic factors (e.g., vegetation structure, species interactions and seed dispersal) and historical factors (e.g., land use) (Scariot 2015).

The state of Santa Catarina located in southern Brazil was once completely covered by the Atlantic Forest, but nowadays it covers $29 \%$ of its original area (Vibrans et al. 2013). In Santa Catarina, 11 species of palms occur naturally as either large arborescent or understory palms: Astrocaryum aculeatissimum (Schott) Burret, Attalea dubia (Mart.) Burret, Butia catarinensis Noblick and Lorenzi, B. eriospatha (Mart. ex Drude) Becc., Euterpe edulis Mart., Syagrus romanzoffiana (Cham.) Glassman and Trithrinax acanthocoma Drude (arborescent palms) (Elias et al. 2016); Bactris setosa Mart., Geonoma elegans Mart., G. gamiova Barb. Rodr. and G. schottiana Mart. (understory palms) (Elias et al. 2018). Palms occur across all vegetation types in the state, but patterns of palm species richness and distribution have yet to be clearly understood.

Here, we analyze the relationship between different aspects of climate and the distribution of native palms species (large arborescent and understory) among the vegetation types found in Santa Catarina, using data from the Floristic and Forest Inventory of Santa Catarina (IFFSC) and WorldClim-GlobalClimateData(Hijmans et al. 2005). We selected four climatic variables commonly reported to constrain plant species distributions (minimum temperature during the coldest month, temperature seasonality, precipitation during the driest extreme quarter, and precipitation seasonality) (following Eiserhardt et al. 2011) and evaluated the effect of these variables on the presence and distribution of palm species in the state. We hypothesized that low temperature and low precipitation limit palm species richness and distribution in Santa Catarina, and that seasonal variation in temperature and precipitation act as secondary factors driving palm distributions.

\section{Materials ANd Methods}

\section{Study area}

The study area encompasses the Southern Brazilian state of Santa Catarina located in the subtropical Atlantic Forest region, with a total area of $95985 \mathrm{~km}^{2}$, of which $12638 \mathrm{~km}^{2}$ is covered by Atlantic Forest (Vibrans et al. 2013; Oliveira et al. 2016). The state's main

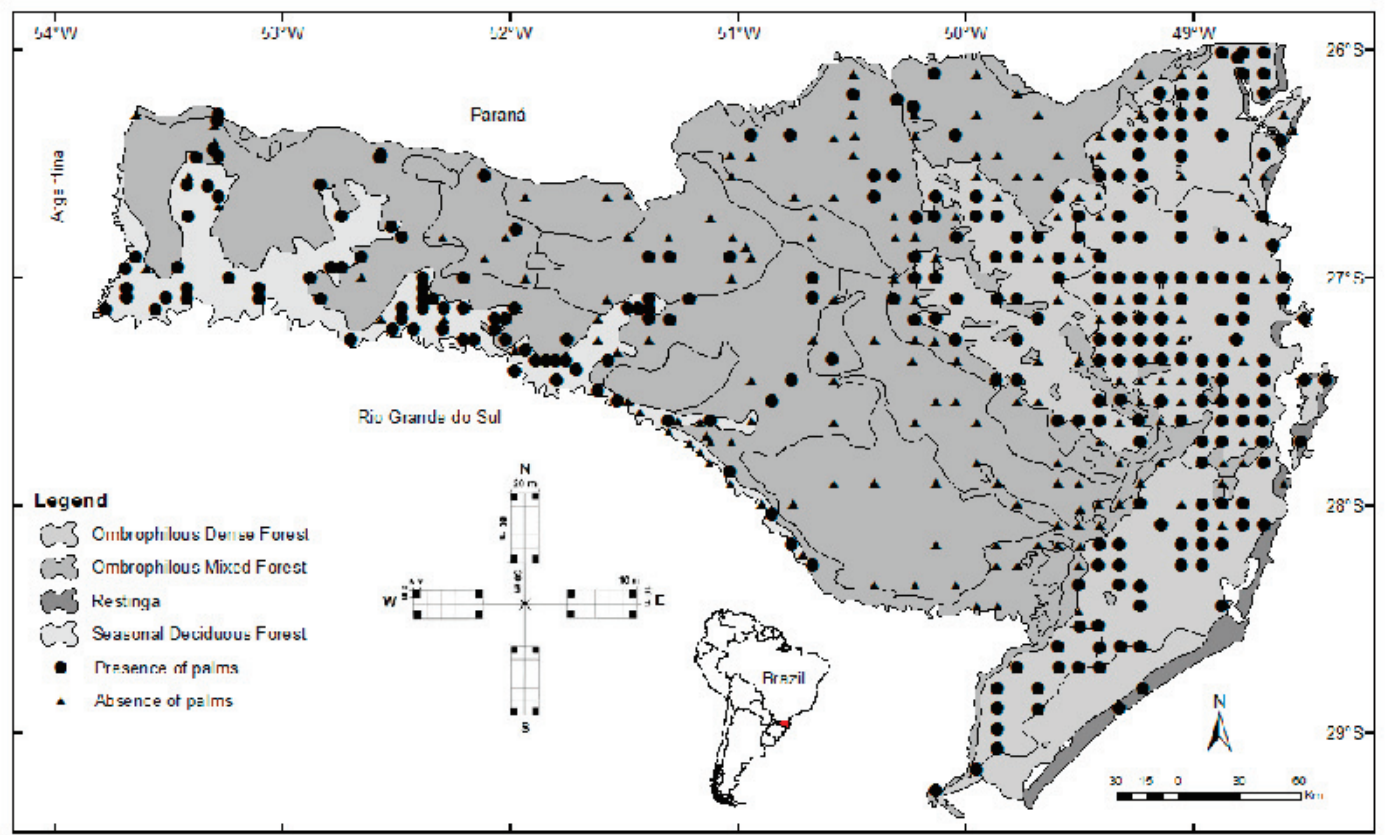

Figure 1. Distribution of Floristic and Forest Inventory of Santa Catarina (IFFSC) sampling units across the State's four Forest Vegetation Types (Klein 1978) and presence and absence of palms.

Figura 1. Distribuição das Unidades Amostrais do Inventário Florístico Florestal de Santa Catarina (IFFSC) nos quatro principais tipos de Vegetação Florestal do Estado (Klein 1978) e a presença e ausência de palmeiras. 
forest types are Ombrophilous Dense Forest (along the Atlantic slope and the quaternary plains, with vegetation forming complex and distinct clusters), Ombrophilous Mixed Forest (vegetation from the plateau of Santa Catarina state, associated with presence of Araucaria angustifolia (Bertol.) Kuntze), Restinga (coastal vegetation) and Seasonal Deciduous Forest (composed of trees that lose their leaves during drought periods) (Klein 1978; IBGE 2012) (Figure 1).

The Köppen climate classification for Santa Catarina is humid subtropical with no defined dry season, and hot (Cfa) or balmy summers $(\mathrm{Cfb})$, corresponding to $40 \%$ and $60 \%$ of the study area, respectively (Alvares et al. 2013). Average annual rainfall varies from 1250 up to $2000 \mathrm{~mm}$, and no areas of the state experience regular drought periods. Average annual temperature varies between $14{ }^{\circ} \mathrm{C}$ to $25^{\circ} \mathrm{C}$ (Nimer 1990).

\section{Data collection}

Data on palm species were obtained from the IFFSC. We analyzed data for all palms recorded in 440 permanent plots (hereafter referred to as sampling units) systematically distributed over a state-wide $10 \times 10 \mathrm{~km}$ grid. Sampling units were located wherever the grid intersected a forest area or fragment $\geq 10 \mathrm{ha}$, and each one consisted in four subplots $(20 \times 50$ $\mathrm{m})$ established in the four cardinal directions for a total area equal to $4000 \mathrm{~m}^{2}$ (Figure 1) (see Vibrans et al. 2010 for details on sampling design). The total sampled area was 176 ha (4000 $\mathrm{m}^{2}$ x 440 sampling units). We analyzed information on large arborescent palms (Diameter at Breast Height $(\mathrm{DBH}) \geq 10 \mathrm{~cm}$ ) and understory palms (DBH $<10 \mathrm{~cm}$, sampled in $5 \times 5 \mathrm{~m}$ plots located in the four corners of each subplot) (Figure 1)

We selected the following climatic variables based on their importance for palm species distributions (following Eiserhardt et al. 2011): temperature seasonality [standard deviation of mean monthly temperature * 100 (BIO4)], minimum temperature during coldest month (BIO6), precipitation seasonality [coefficient of variation of mean monthly precipitation (BIO15)], and precipitation during the driest quarter (BIO17). We believe that these variables best reflect climatic variability (temperature seasonality and precipitation seasonality) and extremes (minimum temperature of the coldest month and precipitation during the driest quarter) and represent important constraints to plant species distributions (Hijmans et al. 2005).

\section{Data analysis}

For modeling palm species richness, we used a generalized linear model for zero inflated data. This modeling strategy allows for finding two sets of limiting factors. The first set separates conditions in which all species are unable to persist. The second set identifies conditions suitable for species to persist, indicating under which conditions a higher diversity of species is expected. Presence or absence of at least one palm species was modeled using a binomial distribution and logit link function. For observed richness with at least one palm individual, we used a negative binomial distribution and logarithmic link function. The four climatic variables were tested as potential predictors of palms species richness, and the resulting model was used to predict palm species richness across the entire study region. We simplified our model based on Akaike Information Criterion (AIC), considering models with $\triangle \mathrm{AIC}<2$ as identical (Burnham and Anderson 2002).

To assess reasons for palm species presence and richness across the state, we used a canonical analysis of principal coordinates (CAP). CAP assesses whether differences in species abundances and composition can be explained by changes in a set of predictors. In this analysis, we again included the four climatic variables as potential predictors and used the Bray-Curtis dissimilarity to describe differences in abundance and species richness among vegetation types. After adjusting the complete model, we proceeded to simplify it based on the adjusted- $\mathrm{R}^{2}$ criteria, stopping when a minimum set of variables no longer exceeded the complete model's adjusted- $\mathrm{R}^{2}$ (Borcard et al. 2011). Statistical analyses were run in the R computing environment ( $\mathrm{R}$ Core Team 2018).

\section{RESULTS}

Out of 440 sampling units, 293 had at least one palm species $(67 \%)$. These sampling units were distributed across all four forest types in Santa Catarina. The recorded species were $A$. dubia, Butia catarinensis, B. eriospatha, E. edulis, S. romanzoffiana and T. acanthocoma (large arborescent palms) (Figure 2), and Bactris setosa, G. elegans, G. gamiova and G. schottiana (understory palms) (Figure 3). Astrocaryum 


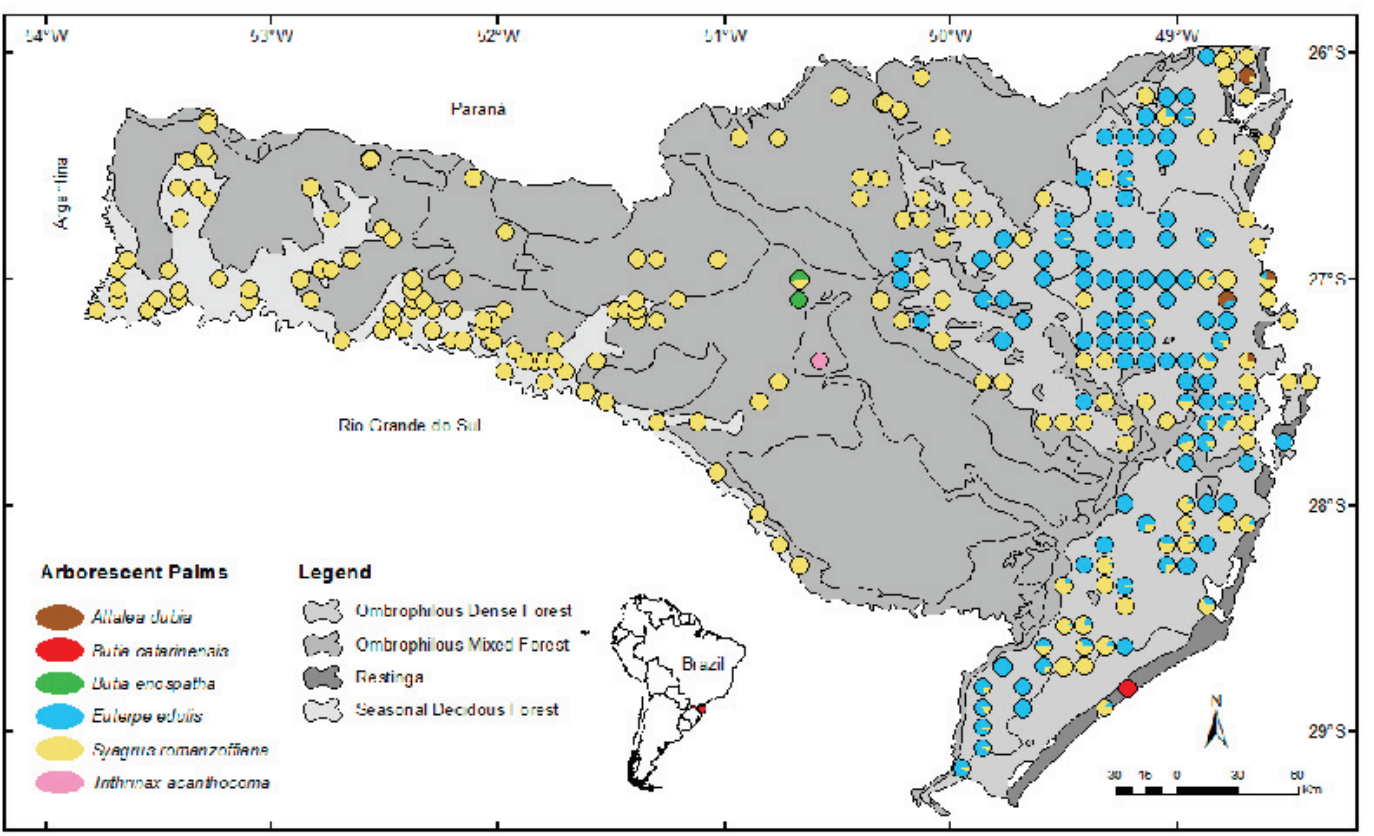

Figure 2. Sampling units from the Floristic and Forest Inventory of Santa Catarina (IFFSC), displaying distribution of large arborescent palm species (Attalea dubia, Butia catarinensis, Butia eriospatha, Euterpe edulis, Syagrus romanzoffiana and Trithrinax acanthocoma) in different Forest Vegetation Types, as described in Klein (1978).

Figura 2. Unidades Amostrais do Inventário Florístico Florestal de Santa Catarina (IFFSC), apresentando a distribuição de espécies de palmeiras arborescentes (Attalea dubia, Butia catarinensis, Butia eriospatha, Euterpe edulis, Syagrus romanzoffiana e Trithrinax acanthocoma) em diferentes Tipos de Vegetação, como descrito em Klein (1978).

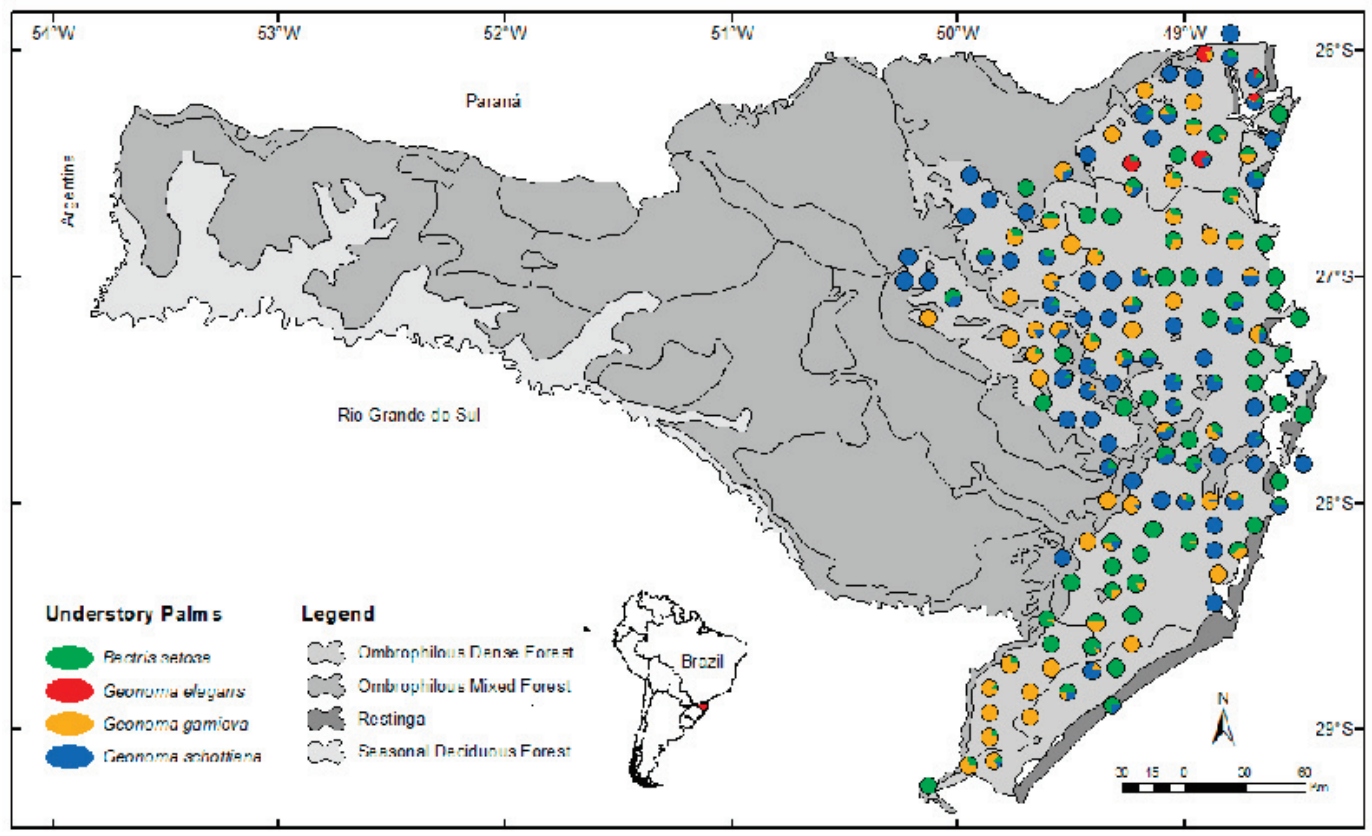

Figure 3. Sampling units from the Floristic and Forest Inventory of Santa Catarina (IFFSC), displaying understory palm species distributions (Bactris setosa, Geonoma elegans, Geonoma gamiova and Geonoma schottiana), in different Forest Vegetation Types as described in Klein (1978).

Figura 3. Unidades Amostrais do Inventário Florístico Florestal de Santa Catarina (IFFSC), apresentando distribuição de espécies de palmeiras arbustivas (Bactris setosa, Geonoma elegans, Geonoma gamiova and Geonoma schottiana) em diferentes Tipos de Vegetação,como descrito em Klein (1978). 
Table 1. Details of the selected count and zero-inflated models for presence and species richness of palms in Santa Catarina. Variables included in the model were temperature seasonality (BIO4), minimum temperature of the coldest month (BIO6), precipitation seasonality (BIO15), and precipitation during the driest quarter (BIO17).

Tabela 1. Detalhes dos modelos de contagem selecionados e inflados de zero para a presença e riqueza de espécies de palmeiras em Santa Catarina. As variáveis incluídas no modelo foram sazonalidade de temperatura (BIO4), temperatura mínima do mês mais frio (BIO6), sazonalidade de precipitação (BIO15) e precipitação durante o trimestre mais seco (BIO17).

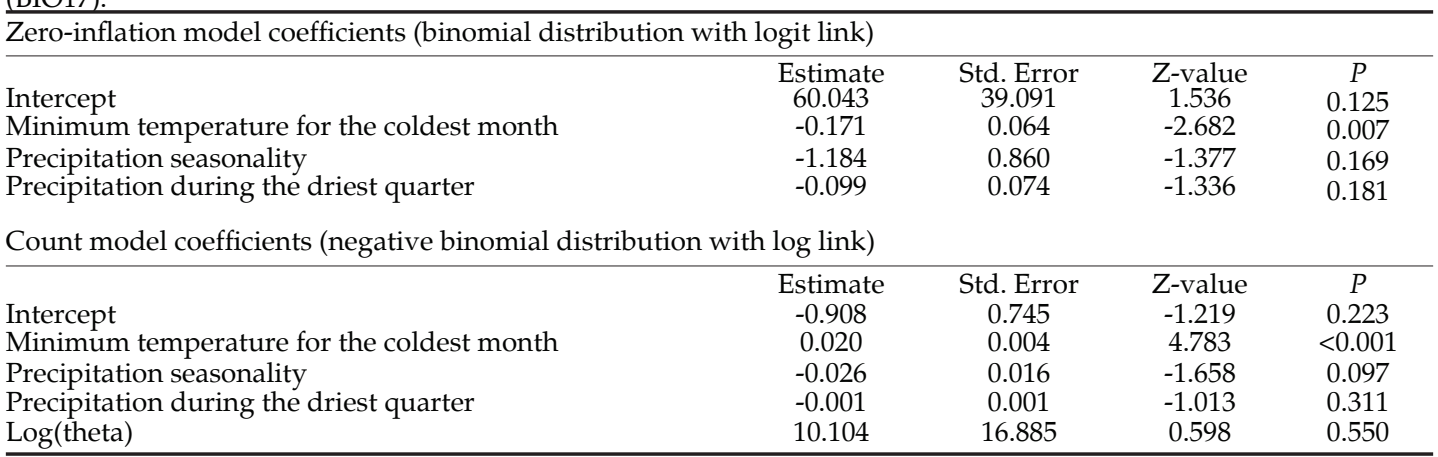

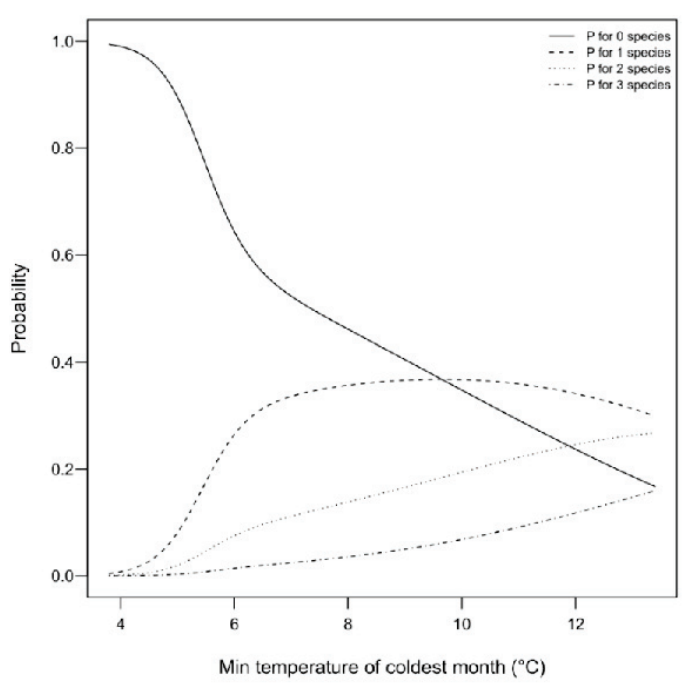

Figure 4. Probabilities for zero, one, two, or three palm species as a function of minimum temperature during coldest month. Other climatic variables were kept constant at their means.

Figura 4. Probabilidades para zero, uma, duas ou três espécies de palmeiras em função da temperatura mínima durante o mês mais frio. Outras variáveis climáticas foram mantidas constantes em suas médias. aculeatissimum was not recorded in any sampling unit.

Large arborescent palms were found across the entire state, but most species distributions were restricted by forest type. Butia catarinensis occurred in only one sampling unit located in Restinga. Attalea dubia and E. edulis were recorded exclusively in Ombrophilous Dense Forest, within five sampling units in the northern part of the state and across 109 sampling units, respectively. Trithrinax acanthocoma and Butia eriospatha exhibited very narrow distributions within Mixed Forest: T. acanthocoma was found in just one sampling unit in Santa Catarina's plateau region, and B. eriospatha occurred in two sampling units. In contrast, $S$. romanzoffiana occurred in all forest types, in 199 sampling units.

All understory palms were found exclusively in Restinga and Ombrophilous Dense Forest. Bactris setosa and G. schottiana occurred in both Ombrophilous Dense Forest and Restinga,

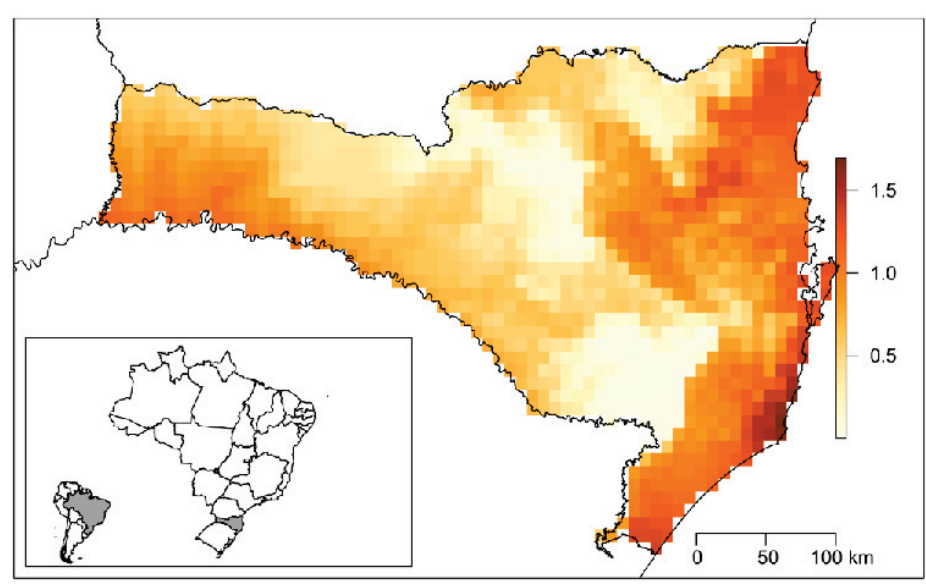

Figure 5. Predicted palm species richness across the Brazilian state of Santa Catarina. Darker areas indicate conditions more suitable for palm species. Lighter areas are mostly highlands above $800 \mathrm{~m}$ elevation.

Figura 5. Riqueza prevista de espécies de palmeiras em todo o estado brasileiro de Santa Catarina. Áreas mais escuras indicam condições mais adequadas para as espécies de palmeiras. As áreas mais claras são na maior parte altitudes elevadas, acima de $800 \mathrm{~m}$. 

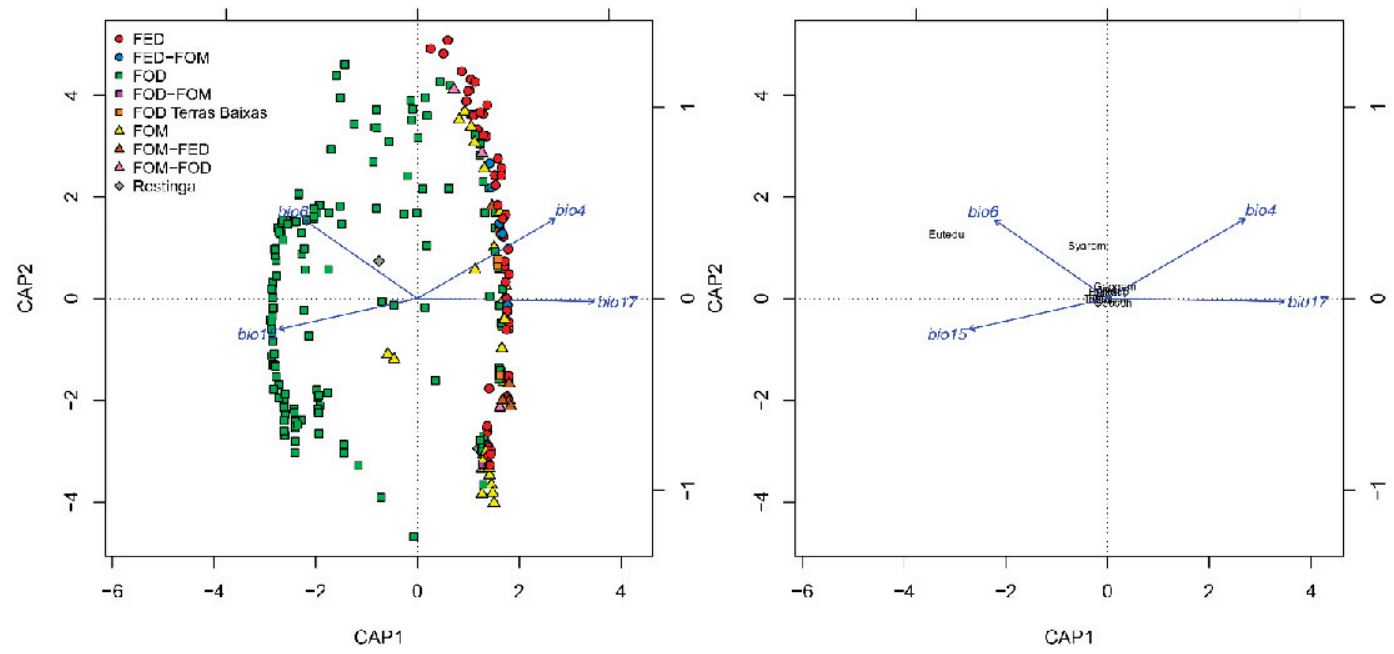

Figure 6. Canonical analysis of principal coordinates for palm distribution and species richness in the Brazilian state of Santa Catarina. Left panel shows the relationship between sites and climatic variables, whereas the right panel shows the relationship between species and climatic variables. Variables included in the model were temperature seasonality (BIO4), minimum temperature for the coldest month (BIO6), precipitation seasonality (BIO15), and precipitation during the driest quarter (BIO17). FED: Seasonal Deciduous Forest, FOD: Ombrophilous Dense Forest, Ombrophilous Mixed Forest: Ombrophilous Mixed Forest.

Figura 6. Análise canônica de coordenadas principais para composição e riqueza de espécies de palmeiras no estado brasileiro de Santa Catarina. O painel esquerdo mostra a relação entre os locais e as variáveis climáticas, enquanto o painel da direita mostra a relação entre as espécies e as variáveis climáticas. As variáveis incluídas no modelo foram sazonalidade de temperatura (BIO4), temperatura mínima para o mês mais frio (BIO6), sazonalidade de precipitação (BIO15) e precipitação durante o trimestre mais seco (BIO17). FED: Floresta Estacional Decidual, FOD: Floresta Ombrófila Densa, FOM: Floresta Ombrófila Mista.

presenting a wide distribution across the eastern part of the State; Bactris setosa was recorded in 101 sampling units and G. schottiana in 83 sampling units. Geonoma elegans and G. gamiova were only found in Ombrophilous Dense Forest. Geonoma elegans occurred in only five sampling units in northern Santa Catarina, while G. gamiova was widely distributed throughout the Ombrophilous Dense Forest.

The full statistical model, containing all four climatic variables, performed best when compared to simpler alternatives. Out of all predictors, minimum temperature displayed the strongest correlations with both presence of palm species (Table 1, zero-inflated model) and palm species richness (Table 1, count model). The probability of encountering at least one species exceeds $40 \%$ where minimum temperature was at least $\sim 7^{\circ} \mathrm{C}$, and species richness increases as minimum temperatures rise (Figures 4 and 5).

Canonical principal coordinates analysis (CAP) separated areas with greater temperature seasonality and higher precipitation during the driest quarter, from areas with greater precipitation seasonality and higher minimum temperature during the coldest month (Figure 6, left panel). These areas correspond to Ombrophilous Dense Forest (FOD), Ombrophilous Mixed Forest (FOM), Restinga (Restinga and FOD Terras Baixas) and Seasonal Deciduous Forest (FED).

The explanatory power of the multivariate model was very low (adjusted- $R^{2}=0.04$ ), indicating that to better explain palm species richness and distribution - especially differences in species abundances, additional covariates are required. Remarkably, the CAP analysis revealed no clear separation in palm species richness between Ombrophilous Mixed Forest and Seasonal Deciduous Forest, two very distinct vegetation types in terms of floristic composition of other plant groups. Only E. edulis and S. romanzoffiana were influenced by the minimum temperature of the coldest month (Figure 6, right panel).

\section{DISCUSSION}

Our results suggest that low temperature extremes influence both the presence of palms and palm species richness in Santa Catarina (Figure 4). In addition, we found increasing 
palm species richness as temperature increases. These results agree with previous findings, suggesting that low temperatures restrict palm species richness and distribution in subtropical regions (Gatti et al. 2008) and is supported by limiting effects of low temperatures in the distribution of other Atlantic Forest plant species (Giehl and Jarenkow 2012; OliveiraFilho et al. 2013; Eisenlohr and Oliveira-Filho 2014; Sevegnani et al. 2016).

Palm inventory and modelling results point to the Ombrophilous Dense Forest as an ideal environment for palm species (Figure 5), since it does not experience low temperatures and rainfall is plentiful. The combination of these two factors is considered important in determining palm species richness and distribution (Morellato et al. 2000; Sesnie et al. 2009). Furthermore, temperature and precipitation together regulate water availability for plants (vapour pressure), by water-energy dynamics such as evapotranspiration, thus playing a key role in palm species distribution, community composition and species richness (Kreft et al. 2006; Salm et al. 2007). Other biotic and abiotic factors, such as soil properties, hydrology, topography, seed dispersal, vegetation structure and species interactions, also affect palm species richness and distribution (Eiserhardt et al. 2011), and represent possible additional covariates for future studies.

Ombrophilous Dense Forest is home to the greatest number of palm species in the State (Figures 2 and 3). The predominance of palm species at lower elevations in Ombrophilous Dense Forest suggests that elevation may be another testable important driver of palm species richness and distribution, since it is strongly correlated with temperature (Reitz 1974; Reis et al. 1996; Svenning 1999). In the Atlantic Forest of São Paulo State, Brazil, Toledo and Fisch (2006) similarly found lower palm species richness at higher altitudes. Other regions of Brazil with high palm species richness, such as the Amazon lowland rain forests (Kahn 1987) and seasonally dry forest (Salm et al. 2007), are also characterized by low elevation, and Amazon palm species distributions have been found to be strongly structured by topography (Svenning 1999).

Regarding the effects of climatic variables on individual palm species, E. edulis showed a high sensitivity to minimum temperature of coldest month (Figure 6), being widespread across Ombrophilous Dense Forest only where minimum temperatures rarely drop below $10^{\circ} \mathrm{C}$ (Figure 2). Gatti et al. (2008) also highlighted the absence of E. edulis in places with cold air drainage. This species is the most abundant palm across the entire state of Santa Catarina (Elias et al. 2016). It is considered a typical species of Ombrophilous Dense Forest in Santa Catarina (Elias et al. 2016), which is characterized by elevated humidity (Reitz 1974). Euterpe edulis grows predominantly below the forest canopy, never exceeding 650 $\mathrm{m}$ altitude (Elias et al. in press), and represents one of the most abundant and common species in the middle forest stratum (Reitz1974).

Syagrus romanzoffiana distribution showed a weaker relationship with minimum temperature than E. edulis (Figure 6), indicating a broader climatic tolerance that allows it to grow in most of Santa Catarina and resulting in no association with any particular forest type (Reitz 1974). Syagrus romanzoffiana is considered well adapted to diverse environments and may even tolerate severe temperature variations, including heavy frost, being used as an alternative feed for cattle during extreme cold events when traditional forage cannot withstand the cold (Reitz 1974). Additionally, it reaches more southern distributions in South America than others palm species from Santa Catarina, occurring in Rio Grande do Sul state and in Argentina and Uruguay (Lorenzi 2010).

Other palm species found in Santa Catarina showed no significant relationship with climatic variables analyzed, because of either small sampled densities or low frequencies (Elias et al. 2018) (Figures 2 and 3) that reflect specialized habitat preferences and narrow geographic distributions (Reitz 1974). For example, the two Butia species occur naturally in grasslands (vegetation associated with Ombrophilous Mixed Forest in this study) (B. eriospatha) and herbaceous restinga (B. catarinensis) - environments not included in the IFFSC survey. Still, these species occurred in areas of forest transition to open vegetation. Furthermore, a long history of forest clearing and land conversion has eliminated specific forest habitats, and, therefore, some palm species now only either colonize or thrive in more open environments (i.e., A. dubia and T. acanthocoma) (Elias et al. 2016). Finally, although $A$. aculeatissimum has previously been listed (Reitz 1974) as native to Santa Catarina, its absence from IFFSC sample plots 
can be at least partially explained by its limited distribution at the northern edge of the state, in the region known as Morro da Brejaúba in the town of Garuva.

The majority of American palm species are understory species (53\%) (Scariot 2015). In our study, understory palms (i.e., B. setosa, G. elegans, G. gamiova and G. schottiana) occurred at low densities (Elias et al. 2018) when compared to arborescent palms mostly because of IFFSC's inclusion criteria (Vibrans et al. 2010): species with DBH less than $10 \mathrm{~cm}$ were sampled in $5 \times 5 \mathrm{~m}$ plots located in the four corners of each larger sampling unit, totaling only $100 \mathrm{~m}^{2}$ at each location. Despite the low understory palm species richness recorded in this study, the above-mentioned species showed high densities and frequencies throughout the Ombrophilous Dense Forest but were absent from all other forest vegetation types in the state (Reitz 1974).
We conclude that species richness and distribution of palms in Santa Catarina are influenced by the current climate, specifically by low temperatures, and precipitation as an associated factor, confirming our initial hypothesis. Additionally, based on our results, the analyses used in this study are more appropriate for abundant species. Despite a general low abundance of understory species, our findings help better understand the overall palm species distribution in Santa Catarina.

AcKnowledgements. The present authors would like to express their thanks to Floristic and Forest Inventory of Santa Catarina team for collecting and sharing the data used in this paper and the financial support from the Foundation for Research and Innovation Support of the State of Santa Catarina and from Coordination for the Improvement of Higher Education Personnel (CAPES) for the first author's scholarship funding.

\section{REFERENCES}

Alvares, C. A., J. L. Stape, P. C. Sentelhas, J. L. M. Gonçalves, and G. Sparovek. 2013. Köppen's climate classification map for Brazil. Meteorologische Zeitschrift 22(6):711-728.

Balslev, H., F. Kahn, B. Millan, J. A. Svenning, T. Kristiansen, F. Borchsenius, D. Pedersen, and W. L. Eiserhardt. Species diversity and growth forms in tropical American palm communities. The Botanical Review 77(4):381-425.

Borcard, D., F. Gillet, and P. Legendre. 2011. Numerical Ecology with R. New York: Springer Science and Business Media.

Burnham, K. P., and D. R. Anderson. 2004. Model selection and multimodel inference: a practical information-theoretic approach. Springer, New York, New York, USA.

Corner, E. J. H. 1966. The Natural History of Palms. Weidenfeld and Nicolson, London, UK.

Dransfield, J., N. W. Uhl, C. B. Asmussen, W. J. Baker, M. M. Harley, and C. E. Lewis. 2008. Genera Palmarum. Richmond, UK: Royal Botanic Gardens, Kew.

Eisenlohr, P. V., L. F. Alves, L. C. Bernacci, M. C. G. Padgurschi, R. B. Torres, B. E. M. Prata, F. A. M. Santos, M. A. Assis, E. Ramos, A. L. C. Rochelle, F. R. Martins, M. C. R. Campos, F. Pedroni, M. Sanchez, and L. S. Pereira. 2013. Disturbances, elevation, topography and spatial proximity drive vegetation patterns along an altitudinal gradient of a top biodiversity hotspot. Biodiversity Conservation 22(12):2767-2783.

Eisenlohr, P. V., and A. T. Oliveira-Filho. 2014. Tree taxa composition in areas of Atlantic Forest in southeastern Brazil is consistent with a new system for classifying the vegetation of South America. Acta Botanica Brasilica 28(2):227233.

Eiserhardt, W. L., J. C. Svenning, D. Kissling, and H. Balsev. 2011. Geographical ecology of the palms (Arecaceae): determinants of diversity and distributions across spatial scales. Annals of Botany 108(8):1391-1416.

Elias, G. A., A. L. Gasper, J. M. T. Lima, K. P. Soares, M. Molz, and R. Santos. 2016. Community Structure of Large Native Arborescent Palms (Arecaceae) using data from the Floristic and Forest Inventory of Santa Catarina, Brazil. Australian Journal of Basic and Applied Sciences 10(10):156-163.

Elias, G. A., A. L. Gasper, J. M. T. Lima, G. Lodetti, and R. Santos. 2018. Native understory palms (Arecaceae) of the Atlantic Forest in Santa Catarina, Southern Brazil. Rodriguésia 69(2):693-698.

Elias, G. A., K. P. Soares, R. L. C. Bortoluzzi, and R. Santos. In press. Palmeiras (Arecaceae) em Santa Catarina, sul do Brasil. Theringia: Série Botânica.

Forzza, R. C., J. F. A. Baumgratz, C. E. M. Bicudo, D. A. L. Canhos, A. A. Carvalho, Nadruz Coelho MA,A. F. Costa, D. P. Costa, M. G. Hopkins, P. M. Leitman, L. G. Lohmann, E. N. Lughadha, L. C. Maia, G. Martinelli, M. Menezes, M. P. Morim, A. L. Peixoto, J. R. Pirani, J. Prado, L. P. Queiroz, S. Souza, V. C. Souza, J. R. Stehmann, L. S. Sylvestre, B. M. T. Walter, and D C. Zappi. 2012. New Brazilian floristic list highlights conservation challenges. Bioscience 62(1):39-45.

Gatti, M. G., P. I. Campanello, L. F. Montti, and G. Goldstein. 2008. Frost resistance in the tropical palm Euterpe edulis and its pattern of distribution in the Atlantic Forest of Argentina. Forest Ecology and Management 256(4):633-640.

Giehl, E. L. H., and J. A. Jarenkow. 2012. Niche conservatism and the differences in species richness at the transition of tropical and subtropical climates in South America. Ecography 35(10):933-943.

Henderson A. 2002. Evolution and Ecology of Palms. New York: The New York Botanical Garden Press. Pp 259. 
Hijmans, R. J., S. E. Cameron, J. L. Parra, P. G. Jones, and A. Jarvis. 2005. Very high-resolution interpolated climate surfaces for global land areas. International Journal of Climatology 25(15):1965-1978.

IBGE. Instituto Brasileiro de Geografia e Estatística. 2012. Manual Técnico da Vegetação Brasileira. Rio de Janeiro: IBGE.

Klein, R. M. 1978.Mapa fitogeográfico de Santa Catarina. Itajaí: Herbário Barbosa Rodrigues.

Kahn, F. 1987. The distribution of palms as a function of local topography in Amazonian Terra-Firme forests. Experientia 43(3):251-259.

Kreft, H., J. H. Sommer, and W. Barthlott. 2006. The significance of geographic range size for spatial diversity patterns in Neotropical palms. Ecography 29(1):21-30.

Lorenzi, H. 2010. Flora Brasileira: Arecaceae (palmeiras). Nova Odessa: Instituto Plantarum.

Lucas, E. J., and Bünger, M. O. 2015. Myrtaceae in the Atlantic forest-their role as a 'model' group. Biodiversity and Conservation 24(9):2165-2180.

Morellato, L. P. C., D. C. Talora, A. Takahasi, C. S. Bencke, E. C. Romera, and V. B. Zipparro. 2000. Phenology of Atlantic rain forest trees: a comparative study. Biotropica 32(4):811-823.

Nimer E. 1990. Climatologia da região sul. Pp. 3-65 in E. Nimer (ed.). Climatologia do Brasil. IBGE/Departamento de Recursos Naturais e Estudos Ambientais, Rio de Janeiro.

Oliveira, L. Z., P. Moser, A. C. Vibrans, G. A. Piazza, A. L. Gasper, and A. T. Oliveira-Filho. 2016. Insights for selecting the most suitable nonparametric species richness estimators for subtropical Brazilian Atlantic Forests. Brazilian Journal of Botany 39(2):593-603.

Oliveira-Filho, A. T., J. C. Budke, J. A. Jarenkow, P. V. Eisenlohr, and D. R. M. Neves. 2013. Delving into the variations in tree species composition and richness across South American subtropical Atlantic and Pampean forests. Journal of Plant Ecology 8(3):242-260.

R Core Team. 2018. R: A language and environment for statistical computing. R Foundation for Statistical Computing, Vienna, Austria. URL: www.R-project.org. Consulted: 07/2018.

Reis, A., P. Y. Kageyama, M. D. Reisand, and A. C. Fantini. 1996. Demografia de Euterpe edulis Martius (Arecaceae) em uma Floresta Densa Montana em Blumenau, SC. Sellowia 45-48:13-45.

Reitz, R. 1974. Palmeiras. Pp. 1-139 in R. Reitz (ed.). Flora Ilustrada Catarinense. Herbário Barbosa Rodrigues, Itajaí, Brasil.

Salm, R., N. V. Salles, W. J. Alonso, and C. Schuck-Paim. 2007. Cross-scale determinants of palm species distribution. Acta Amazonica 37(1):17-25.

Scariot, A. O. 2015. Palmeiras brasileiras: botânica, ecologia, usos e conservação. Pp. 15-33 in R. Lopes, M. S. P. Oliveira, M. M. Cavallari, R. L. Barbieri and L. D. H. C. S. Conceição (eds.). Palmeiras Nativas do Brasil. Embrapa, Brasília, Brasil.

Sesnie, S. E., B. Finegan, P. E. Gessler, and Z. Ramos.2009. Landscape-scale environmental and floristic variation in Costa Rican old-growth rain forest remnants. Biotropica 41(1):16-26.

Sevegnani, L., A. Uhlmann, A. L. Gasper, L. Meyer, and A. C. Vibrans. 2016. Climate affects the structure of mixed rain forest in southern sector of Atlantic domain in Brazil. Acta Oecologica 77:109-177.

Svenning, J. A.1999. Microhabitat specialization in a species-rich palm community in Amazonian Ecuador. Journal of Ecology 87(1):55-65.

Svenning, J. A., F. Borchsenius, S. Bjorholm, and H. Balsev. 2008. High tropical net diversification drives the New World latitudinal gradient in palm (Arecaceae) species richness. Journal of Biogeography 35(3):394-406.

Toledo, M. C. B., and S. T. V. Fisch. 2006. Bases cartográficas para armazenamento e análise espacial de dados da diversidade de palmeiras em um trecho de Mata Atlântica, Ubatuba-SP. Biota Neotropica 6(1):1-13.

Tomlinson, P. B. 2006. The uniqueness of palms. Botanical Journal of the Linnean Society 151:5-14.

Vibrans, A. C., L. Sevegnani, D. V. Lingner, A. L. Gasper, and S. Sabbagh. 2010. Inventário Florístico Florestal de Santa Catarina (IFFSC): aspectos metodológicos e operacionais. Pesquisa Florestal Brasileira 30(64):291-302.

Vibrans, A. C., R. E. McRoberts, P. Moser, and A. L. Nicoletti. 2013. Using satellite image-based maps and ground inventory data to estimate the remaining Brazilian Atlantic forest in Santa Catarina. Remote Sense Environment 130:87-95. 